囚Л. А. Іванова

Буковинський державний медичний університет

\title{
ЕФЕКТИВНІСТЬ ЛІКУВАЛЬНИХ ЗАХОДІВ У ПЕРІОД ЗАГОСТРЕННЯ ТЯЖКОЇ БРОНХІАЛЬНОЇ АСТМИ В ШКОЛЯРІВ
}

\begin{abstract}
ЕФЕКТИВНІСТЬ ЛІКУВАЛЬНИХ ЗАХОДІВ У ПЕРІОД ЗАГОСТРЕННЯ ТЯЖКОЇ БРОНХІАЛЬНОЇ АСТМИ В ШКОЛЯРІВ. 3 метою підвищення ефективності лікувальних заходів у період загострення тяжкої бронхіальної астми в школярів на підставі оцінки особливостей дезобструктивної терапії нападного періоду обстежено 70 хворих на тяжку бронхіальну астму та 92 їх однолітки із середньотяжким перебігом захворювання. Установлено, що в пацієнтів I групи під час нападу тяжкої'астми вірогідно частіше використовувались ГКС системної'дії' $((85,7 \pm 4,1) \%)$, ніж у хворих групи порівняння $((56,5 \pm 5,2) \%, p<0,05)$. Крім того, у школярів із тяжкою бронхіальною астмою вдвічі частіше $((37,1 \pm 5,7)$ \%) застосовувалися в-2-агоністи короткої' дії' в поєднанні із системними ГКС, ніж у їх однолітків із середньотяжким перебігом захворювання $((15,2 \pm 3,6) \%, p<0,05)$. В роботі показано, що зниження абсолютного ризику використання системних глюкокортикостероїдів у дітей із середньотяжким перебігом захворювання відносно хворих на тяжку астму склало 29,2 \%, відносного ризику - 34,1 \% при ЧХНП 3,4 пацієнтів. Доведено, що бронхообструкція впродовж перших трьох днів загострення вірогідно тяжча у дітей з тяжкою бронхіальною астмою та виразним запаленням бронхів, ніж у хворих з помірною інтенсивністю запалення дихальних шляхів. Зниження абсолютного ризику використання глюкокортикостероїдів та еуфіліну при тяжкій бронхіальній астмі у «швидких» відносно «повільних» ацетиляторів склало 4,2 та $25,7 \%$, відносного ризику - 5,0 та $34,9 \%$ при ЧХНП 23,8 та 3,9 хворих відповідно.
\end{abstract}

ЭФФЕКТИВНОСТЬ ЛЕЧЕБНЫХ МЕРОПРИЯТИЙ В ПЕРИОД ОБОСТРЕНИЯ ТЯЖЕЛОЙ БРОНХИАЛЬНОЙ АСТМЫ У шкОЛЬНИКОВ. С целью повышения эффективности лечебных мероприятий в период обострения тяжелой бронхиальной астмы у школьников на основании оценки особенностей дезобструктивной терапии приступного периода обследовано 70 больных тяжелой бронхиальной астмой и 92 их сверстника со среднетяжелым течением заболевания. Установлено, что у пациентов I группы во время приступа тяжелой астмы достоверно чаще использовались глюкокортикостероиды системного действия $((85,7 \pm 4,1) \%)$, чем в группе сравнения $((56,5 \pm 5,2) \%$, p <0,05). Кроме того, у школьников с тяжелой бронхиальной астмой в два раза чаще $((37,1 \pm 5,7) \%)$ применялись в-2-агонисты короткого действия в сочетании с системными глюкокортикостероидами, чем у их сверстников со среднетяжелым течением заболевания $((15,2 \pm 3,6) \%, p<0,05)$. В работе показано, что снижение абсолютного риска использования системных глюкокортикостероидов у детей со среднетяжелым течением заболевания по отношению к больным тяжелой астмой составило 29,2 \%, относительного риска - 34,1 \% при ЧБНП 3,4 пациентов. Доказано, что обструкция в течение первых трех дней обострения достоверно тяжелее у детей с тяжелой бронхиальной астмой и выраженным воспалением бронхов, чем у больных с умеренной интенсивностью воспаления дыхательных путей. Снижение абсолютного риска использования глюкокортикостероидов и эуфиллина при тяжелой бронхиальной астме у «быстрых» относительно «медленных» ацетиляторов составило 4,2 и 25,7 \%, относительного риска - 5,0 и 34,9 \% при ЧБНП 23,8 и 3,9 больных соответственно.

EFFICIENCY OF MEDICAL ACTIONS DURING THE SEVERE BRONCHIAL ASTHMA EXACERBATION IN SCHOOLCHILDREN. Order to increase efficiency of medical measures during the exacerbation of severe bronchial asthma in schoolchildren based on the peculiarities of relief therapy of asthma attack were examined 70 patients with severe asthma and 92 their peers with moderate variant of disease. Was established that patients of I group during an attack of severe asthma used systemic corticosteroids significantly more times $(85.7 \pm 4.1 \%)$, than patients of comparison group $56.5 \pm 5.2 \%(P<0.05)$. Schoolchildren with severe asthma $(37.1 \pm 5.7 \%)$ used short-acting B-2 agonists in combination with systemic corticosteroids twice more often than their peers with moderate variant of disease $(15.2 \pm 3,6 \%, p<0.05)$. It is shown that the absolute risk reduction of systemic corticosteroids use in children with moderate disease to compare of severe asthma patients was $29.2 \%$, relative risk reduction - $34.1 \%$ and NNT - 3.4 patients. It is proved that bronchial obstruction during the first three days of exacerbation significantly too severe in children with severe asthma and expressive bronchial inflammation than in patients with moderate intensity of airway inflammation. Absolute risk reduction of the use of corticosteroids and euphylline in patients, who suffered from severe asthma with "fast" acetylation to compare of children with "slow» acetylation, was $4.2 \%$ and $25.7 \%$, relative risk reduction - $5.0 \%$ and $34.9 \%$ and NNT - 23.8 and 3.9, respectively.

Ключові слова: бронхіальна астма, запалення дихальних шляхів, ефективність лікування.

ключевые слова: бронхиальная астма, воспаление дыхательных путей, эффективность лечения.

Key words: bronchial asthma, airway inflammation, treatment efficacy.

ВСТУп. Бронхіальна астма (БА) розглядається як хронічне захворювання, що виникає при взаємодії різноманітних генів із численними факторами навколишнього середовища. В останні десятиріччя отримано нові дані щодо патогенезу захворювання, які свідчать, що бронхіальна астма - це комплексна гетерогенна група, що складається 3 багатьох френотипів. Останні характеризуються притаманною клінічною картиною, відмінностями щодо етіології та патогенезу, а також ефективності лікування [1-3]. 


\section{Педіатрія}

Найбільшу цікавість у практичних лікарів та дослідників наразі викликає тяжка бронхіальна астма, оскільки даний фенотип асоціює з широким спектром невирішених медико-соціальних проблем, несе серйозну загрозу життю і призводить до зниження його якості [4-6]. Тяжка астма, у свою чергу, розглядається нині як гетерогенне захворювання, що складається 3 різних субфенотипів, певними ознаками яких виступають характер та активність запалення бронхів, чутливість до лікування глюкокортикостероїдами (ГКС), гіперсприйнятливість бронхів та фріксована обструкція дихальних шляхів [7]. Оцінка ефективності лікувальних заходів у хворих із фенотипом тяжкої бронхіальної астми дозволить оптимізувати терапію цих хворих та в подальшому розробити індивідуалізовані підходи до лікування.

Мета роботи - підвищити ефективність лікувальних заходів у період загострення тяжкої бронхіальної астми в школярів на підставі оцінки особливостей дезобструктивної терапії нападного періоду.

МАТЕРІАЛИ ТА МЕТОДИ. ДЛЯ оцінки результатів лікування хворих на тяжку БА сформовано 2 клінічні групи спостереження. До I клінічної групи увійшло 70 хворих на тяжку БА, до групи порівняння - 92 їх однолітки із середньотяжким перебігом захворювання. За основними клінічними характеристиками групи порівняння були зіставлюваними. Середній вік хворих I клінічної групи становив $(11,9 \pm 0,4)$ року, а пацієнтів групи порівняння - $(11,3 \pm 0,3)$ року. Серед дітей із тяжкою БА хлопчиків було $(67,1 \pm 5,6) \%$, а мешканців міста - $(37,1 \pm 5,8) \%$. У групі порівняння вказані показники становили, відповідно, $(47,8 \pm 5,2) \%(p>0,05)$ та $(39,4 \pm 4,8) \%(p>0,05)$. Усі діти комплексно обстежувались у пульмоалергологічному відділенні ОДКЛ м. Чернівці. Лікування хворих на БА визначалося згідно із затвердженим МОЗ України протоколом діагностики та лікування бронхіальної астми у дітей $[8,9]$

При госпіталізації хворих у стаціонар тяжкість бронхообструктивного синдрому під час періоду загострення захворювання оцінювали за бальною шкалою. Зростання оцінки за бальною шкалою відображало посилення проявів цього синдрому.

Тип ацетилювання визначали за методом Пребстинг та Гаврилова у модифікації Тимофєєвої (1971) за допомогою фотоелектроколориметра [10]. Конденсат видихуваного повітря (КВП) отримували у позанападний період за допомогою спроектованого та модифікованого конденсора. Вміст метаболітів монооксиду нітрогену в КВП визначали за Н. Л. Ємченко [11].

Статистичну обробку одержаних результатів проводили на персональному комп'ютері з використанням пакета прикладних програм 3lallБIlca 5.0. Ефективність лікування оцінювали за зниженням абсолютного (ЗАР) та відносного ризиків (ЗВР) з урахуванням мінімальної кількості хворих, яких необхідно пролікувати для отримання одного позитивного результату (ЧХНП).

РЕЗУЛЬТАТИ ДОСЛІДЖЕННЯ ТАЇХ ОБГОВОРЕН-

ня. У роботі показано, що на початку загострення тяжкість бронхообструкції (в балах) у дітей груп порівняння суттєво не відрізнялась. Все ж у дітей із тяжкою БА на 3-й та 7-й дні лікування виразність бронхообструкції була дещо більшою, ніж у пацієнтів із середньотяжким перебігом захворювання. Так, відносний ризик збереження тяжкості бронхообструкції (більше 13 балів на 3-й день лікування) у хворих на тяжку бронхіальну астму відносно середньотяжкої форми захворювання становив 1,2 (95\% ДІ: 0,6-2,4), пропорційність шансів складала 1,4 (95\% ДІ: 0,6-3,2) при абсолютному ризику 0,1. Показник відносного ризику збереження тяжкості бронхообструкції (більше 7 балів на 7-й день лікування) у хворих на тяжку БА відносно середньотяжкої форми захворювання становив 1,6 (95 \% ДІ: 0,5-5,5), пропорційність шансів складала 3,5 (95 \% ДІ: 0,9-12,8) при абсолютному ризику 0,3.

Установлено, що в пацієнтів I групи під час нападу тяжкої астми вірогідно частіше використовувались ГКС системної дії $((85,7 \pm 4,1) \%)$, ніж у хворих групи порівняння $((56,5 \pm 5,2) \%, p<0,05)$. Зниження абсолютного ризику застосування системних ГКС у дітей групи порівняння відносно хворих на тяжку астму склало 29,2 \%, відносного ризику - 34,1 \% при ЧХНП 3,4 пацієнтів.

Аналіз ефективності дезобструктивної терапії загострень БА у дітей клінічних груп показав, що монотерапія сальбутамолом вірогідно частіше $((34,7 \pm 4,9) \%)$, а в комбінації з метилксантинами дещо частіше $((9,8 \pm 2,7) \%)$ застосовувалась при середньотяжкій астмі, ніж у пацієнтів із тяжкою БА $((8,6 \pm 3,8) \% ; p<0,05$ та $(5,7 \pm 2,7) \%$; p $>0,05)$ відповідно. Установлено, що в пацієнтів із тяжкою БА вдвічі частіше $((37,1 \pm 5,7) \%)$ використовувалися р-2-агоністи короткої дії в поєднанні із системними ГКС, ніж у їх однолітків із середньотяжким перебігом захворювання $((15,2 \pm 3,6) \% ; p<0,05)$. Відмічено, що кожна друга дитина з тяжкою БА потребувала поєднаного використання усіх трьох груп дезобструктивних лікарських засобів $((48,6 \pm 5,9) \%)$, у хворих із середньотяжкою астмою така комбінація застосовувалась рідше - у $(40,2 \pm 5,1) \%$. Близько половини школярів обох клінічних груп у процесі дезобструктивноїтерапії отримували препарати метилксантинів для перорального або внутрішньовенного приймання.

Беручи до уваги те, що тяжкість БА визначається її фенотипічними ознаками, зокрема інтенсивністю запального процесу в дихальних шляхах, маркером якого $€$ монооксид нітрогену, вважали доцільним дослідити залежність тяжкості нападу БА від інтенсивності запального процесу в бронхах (рис. 1). Виразним вважали запальний процес, за якого вміст метаболітів МОН у КВП становив більше 40 мкмоль/л, референтну групу склали хворі на тяжку БА, в яких вміст вказаних метаболітів був меншим 40 мкмоль/л.

Доведено, що бронхообструкція впродовж перших трьох днів загострення виявилася вірогідно тяжчою у дітей I клінічної групи за виразного запалення бронхів, ніж у школярів 3 помірною інтенсивністю запалення. Виразніша бронхообструкція у хворих за вмісту в КВП МОН більше 40 мкмоль/л зумовила частішу необхідність приймання системних ГКС $(87,5 \%)$ та застосування інфузійної терапії з еуфіліном $(41,6 \%)$, ніжу пацієнтів з помірною інтенсивністю запального процесу - 77,3\% (Рфр>0,05) та $31,8 \%$ $(P \phi>0,05)$ пацієнтів відповідно.

Оскільки БА $€$ генетично детермінованим захворюванням, а швидкість ацетилювання вважається 


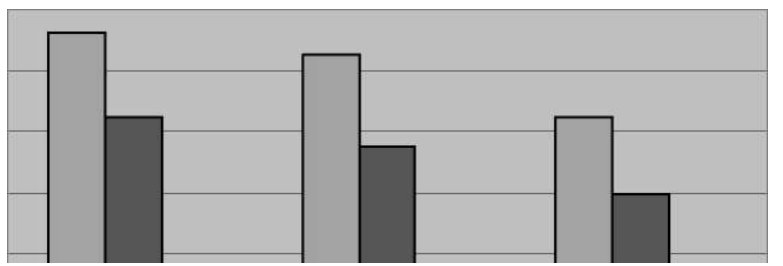

\begin{tabular}{|l|c|c|c}
\cline { 2 - 4 } \multicolumn{1}{c|}{} & 1 день & II день & III день \\
\hline • виразне запалення & 11,2 & 10,5 & 8,5 \\
\hline • помірне запалення & 8,5 & 7,5 & 6 \\
\hline - P & 0 & 0 & 0 \\
\hline
\end{tabular}

Рис. 1. Тяжкість нападу тяжкої БА за різної інтенсивності запалення бронхів.

однією з генетичних міток активності метаболічних процесів в організмі, вважали доцільним вивчити залежність відповіді на лікування пацієнтів із тяжкою БА від швидкості ацетилювання. Незважаючи на припущення проте, що використання глюкокортикостероїдів більш ефективне та раціональне у хворих зі швидким типом ацетилювання, оскільки їх дія направлена на апоптоз еозинофілів, а метилксантини посилюють протизапальний процес при еозинофільному типі запалення в бронхах, у нашому дослідженні відмічено, що, навпаки, у пацієнтів із повільним типом ацетилювання дещо частіше використовувались системні ГКС $((84,2 \pm 8,3) \%)$ й еуфілін внутрішньовенно $((73,7 \pm 10,5) \%)$. У хворих з швидким типом ацетиляторних механізмів зазначені лікарські засоби застосовувалися у $(80,0 \pm 8,0)$ та $(48,0 \pm 9,9) \%$ випадків (Рф>0,05) відповідно. При цьому ЗАР використання ГКС та еуфіліну в «швидких» відносно «повільних» ацетиляторів склало 4,2 та $25,7 \%$, 3ВР - 5,0 та $34,9 \%$ при ЧХНП 23,8 та 3,9 хворих відповідно.

\section{СПИСОК ЛІТЕРАТУРИ}

1. Fashy J. V. Identifying Clinical Phenotypes of asthma / J. V. Fashy // Am. J. Respir. Crit. Care Med. - 2010. Vol. 181. - P. 296-297.

2. Уманец Т. Р. Фенотипи формування бронхіальної астми у дітей дошкільного віку / Т. Р. Уманец // Астма та алергія. - 2012. - № 1. - С. 18-22.

3. Чикина С. Ю. Новый взгляд на фенотипы бронхиальной астмы / С. Ю. Чикина // Атмосфера. Пульмонология и аллергология. - 2012. - № 2. - С. 2-6.

4. Carlsen $\mathrm{K}-\mathrm{H}$. Childhood asthma in the Year of the lung / K-H. Carlsen, G. Hedlin, A. Bush // Eur. Respir. J. 2010. - Vol. 36. - P. 6-7.

5. Трофимов В. Терапевтически резистентная бронхиальная астма / В. Трофимов, Ж. Миронова // Врач. - 2012. - № 3. - С. 2-4.

6. Княжеская Н. П. Тяжелая, трудно контролируемая бронхиальная астма / Н. П. Княжеская // Атмосфера. Пульмонология и аллергология. - 2012. № 1. - C. 16-19.
ВИСНОВКИ. 1. Зниження абсолютного ризику використання системних глюкокортикостероїдів у дітей із середньотяжким перебігом захворювання відносно хворих на тяжку астму склало 29,2 \%, відносного ризику - 34,1 \% при ЧХНП 3,4 пацієнтів.

2. Бронхообструкція впродовж перших трьох днів загострення вірогідно тяжча у дітей з тяжкою бронхіальною астмою та виразним запаленням бронхів, ніж у хворих з помірною інтенсивністю запалення дихальних шляхів.

3. Зниження абсолютного ризику використання глюкокортикостероїдів та еуфіліну при тяжкій бронхіальній астмі у «швидких» відносно «повільних» ацетиляторів склало 4,2 та 25,7 \%, відносного ризику 5,0 та $34,9 \%$ при ЧХНП 23,8 та 3,9 хворих відповідно.

ПЕРСПЕКТИВИ ПОДАЛЬШИХ ДОСЛІДЖЕНЬ. ПОдальші дослідження полягатимуть у дослідженні ефективності швидкодопоміжної та контролюючої терапії при еозинофільному, атопічному фенотипі, бронхіальній астмі фізичної напруги у дітей з метою розробки індивідуалізованих підходів до лікування.

7. Fleming L. Difficalt to control asthma in children / L. Fleming, N. Wilson, A. Bush // Curr. Opin. Allergy Clin. Immunol. - 2007. - Vol. 7, №. 2. - 190-195.

8. Протокол діагностики та лікування бронхіальної астми у дітей : наказ МО3 України №767 від 27.12.2005 p.

9. Уніфікований клінічний протокол первинної, вторинної меддопомоги. Бронхіальна астма у дітей : наказ МО3 України № 868 від 08.10.2013 р.

10. Прунчак С. І. Особливості лікування нападного періоду тяжкої форми бронхіальної астми в дітей шкільного віку залежно від типу ацетилювання / C. І. Прунчак // Буковинський медичний вісник. 2006. - T. 10, № 1. - С. 61-64.

11. Емченко Н. Л. Универсальный метод определения нитратов в биосредах организма / Н. Л. Емченко, О. И. Цыганенко, Т. В. Ковалевская // Клиническая и лабораторная диагностика. - 1994. - № 6. - С. 19-20.

Отримано 11.02.15 